\title{
University Student Satisfaction and Skill Acquisition: Evidence from the Undergraduate Dissertation
}

\author{
Fidel Martínez-Roget ${ }^{1, * \mathbb{C}}$, Pilar Freire Esparís ${ }^{1}$ and Emilia Vázquez-Rozas ${ }^{2}$ \\ 1 Department of Applied Economics, University of Santiago de Compostela, Avda. Xoán XXIII, s/n, \\ 15782 Santiago de Compostela, Spain; mdelpilar.freire@usc.es \\ 2 Department of Quantitative Economics, University of Santiago de Compostela, Avda. Xoán XXIII, s/n, \\ 15782 Santiago de Compostela, Spain; emilia.vazquez@usc.es \\ * Correspondence: fidel.martinez@usc.es; Tel.: +34-881-811-51
}

Received: 18 December 2019; Accepted: 22 January 2020; Published: 25 January 2020

\begin{abstract}
One of the main objectives of the Undergraduate Dissertation is to evaluate the skills associated with a degree. Student satisfaction with the training and skills acquired can be an indicator of the quality of higher education. This paper aims to analyse student satisfaction with Undergraduate Dissertation at the Faculty of Economics of the University of Santiago de Compostela (Spain). Based on a survey conducted among 130 students $(75.7 \%$ of a total of 172 students who presented their UD during the academic year 2013-2014), structural equation modelling was applied to analyse the influence on satisfaction of aspects related to intellectual curiosity and the perception of acquired skills. The results show that the perception of the skills acquired play a crucial role in students' satisfaction with Undergraduate Satisfaction, conditioned by their perceived future usefulness and backed by personality and motivation elements that encourage their acquisition. The results confirm the significant role played by the tutor, who emerges as an element that boosts the central relations of the model.
\end{abstract}

Keywords: Satisfaction; skills; higher education; motivation

\section{Introduction}

Higher education in Spain has undergone a number of major changes in recent years. Together with the implantation of the European Higher Education Area (EHEA), there has been a significant reduction in the number of students and public funding, coupled with growing concerns by the authorities regarding quality and efficiency.

One of the problems affecting higher studies is their failure to meet society's current and future demands [1]. Precisely one of the aims of the EHEA is to achieve greater competitiveness in the labour and professional market for European graduates in the face of new international competitors. In order to achieve this, training must be at least partially oriented to meeting market needs. University education is therefore a requirement to access professional status that will have a major impact on the future of the individual.

Student satisfaction plays an important role in the quality of university education. Identifying students' degree of satisfaction with their education and acquired skills, or knowing their opinions regarding how closely this education and these skills are adapted to the demands of an increasingly flexible job market, can be a good indicator of how well the process is working. We must not forget that students tend to be seen primarily as customers in the higher education system [2]. It can also contribute valuable information for the application of ongoing improvements in education [3].

In Spain, the National Agency for Quality Assurance in Higher Education (ANECA) assesses university degrees in order to renew their accreditation. Its objectives include verifying the results 
obtained for each degree course by analysing the mechanisms each university applies in order to validate students' effective acquisition of the initially defined skills. The accreditation process includes an analysis of satisfaction levels amongst students, teaching staff, graduates and other stakeholders.

One of the most important new aspects of the EHEA is the obligatory requirement to present an Undergraduate Dissertation (UD). The UD represents the culmination of the degree course, and therefore the moment when students have to demonstrate the competences they have acquired. It can be considered a way of defining and examining the generic competences sought by the Bologna Declaration and the Tuning project [4].

Although the importance of the UD varies between degree courses, students need to use a wide range of skills and dedicate a considerable amount of time and effort to completing it. The process of producing a UD should enable students to achieve a series of competences, such as the ability to plan and organise, problem solving and self-criticism [5].

As the UD is written at the end of the degree course, it could be considered that its quality and defence are a reflection of the quality of the educational programme as a whole, both in terms of the competences achieved during the writing thereof and those acquired when carrying out the work. We believe that the competences derived from the UD will be those that have a direct effect on students' satisfaction with the subject. As [6] indicates (p. 2):

"The key to success in degree studies may be adapting the study plans to achieving specific competences and meeting the students' expectations in terms of their insertion in the socio-professional reality of the twenty-first century, thereby achieving a high level of satisfaction while they are studying and once they have left university".

In many Spanish universities, the UD was introduced in the academic year 2012-2013, as degree courses were gradually applied. Due to their recent introduction, there are still only a few studies that analyse the experience with UDs in Spanish universities. However, the UD is a topic of interest and numerous articles have been published in scientific journals [7,8]. One of the main objectives of this study will be to shed light on this topic, analysing the level of satisfaction with the UD among students of Economics and Business Management at the University of Santiago de Compostela, Spain.

\subsection{Student Satisfaction}

Satisfaction is usually defined as an opinion based on the experience that customers have with a product or service, in comparison to their prior expectations. Since early studies in Social Cognitive Career Theory by $[9,10]$, a considerable amount of research has been conducted based on these models, which focus on the relevance of self-efficacy, expected outcome and the other personal and environmental supports for career development and life satisfaction, as well as college students' satisfaction like [11-13]. This research indicates the significance of cognitive and behavioral variables, such as self-efficacy beliefs or outcome expectations of students' academic performance. The work by $[14,15]$ also analyses the role of non- intellective competences in university students' satisfaction, rather than just their academic performance. We consider that student satisfaction can be considered in a similar manner, and can be defined in different ways: (1) as an attitude resulting from an evaluation of the educational experience of the students, or (2) as a subjective evaluation of various results and experiences related to education and student life [16]. Literature on student satisfaction in higher education has considered a range of aspects from various perspectives. Some studies have focused on the level of student satisfaction with one or more subjects [17-24], whilst others address satisfaction with university degrees or university institutions [25,26]. In many of these studies, satisfaction is associated with other variables such as utility, motivation or skills acquisition, albeit not jointly.

Student satisfaction with a subject, activity or specific teaching method is usually associated with the expected or obtained usefulness. For example, the study by [19], which is based on combined learning, analyses three aspects associated with students' perception: the utility attributed to the course; how it affects their motivation to learn; and their degree of satisfaction with this teaching tool. 
The authors conclude that the students' perception of the utility of the online activities is correlated with their motivation and satisfaction.

\subsection{Skills Perception}

One of the main objectives of the UD is to assess the skills associated with a degree. The quality of the UD may therefore reflect the quality of the degree course itself. Similarly, students' satisfaction with the skills acquired will depend on the extent to which their expectations regarding their incorporation on the labour market are met; in other words, with perceived utility. On the one hand, analysing students' satisfaction with the UD may serve to evaluate the competences provided by university degree courses, and on the other, to test how closely in line these competences are with the requirements of the job market from the perspective of the future professional. Therefore, as in works such as [27] overall satisfaction is the dependent variable. As [28] has discussed, this has several advantages: Overall satisfaction affects major outcomes such as persistence and graduation; overall satisfaction determines loyalty and understanding, thereby contributing to international students' overall satisfaction and helping institutions to serve, retain, and recruit students.

As the acquisition of competences is generally associated with the perception of utility and the impact on students' future professional career, Ref. [29] consider that perceptions of academic skills can be a predictor of satisfaction.

\subsection{Motivation}

A wide range of academic and social factors with potential effects come into play in producing UDs. Obviously, not all students attain the same level of competences. The novelty and complexity of the tasks calls for a certain degree of motivation. Motivation has been identified as a key determinant of academic performance [30]. Students who are highly motivated value learning tasks for their importance and utility. However, students who have little motivation prefer easy tasks, where interest or cost take precedence over their utility.

Student engagement is a complex issue. It includes many factors that interact in multiple ways [31]. The findings of [32] suggest "student motivations may be used to predict cognitive engagement in active, project-based environments". In particular, highly motivated students have a success-oriented attitude, are involved in activities, and strive to do well. However, students with a low level of motivation maintain attitudes aimed at preventing failure (delaying tasks) and are unconcerned with completing them correctly. In all likelihood, the driving force that leads certain students to acquire more and better capacities is partially linked to personality traits. If, as we have suggested, they are faced with a new and complex task, individuals who prefer intellectual challenges will be more motivated, and acquire competences of greater value.

\subsection{Intellectual Curiosity}

Intellectual curiosity is a complex and often not well defined concept. As pointed by [33] intellectual curiosity is often confused with other terms such as interest, openness to experience or novelty-seeking. Although some authors like [34] have more concretized this concept and they consider curiosity as a cognitive strength that entail the acquisition and use of knowledge. Curiosity can be defined as having interest in the new experiences, in exploring and discovering and in finding all subjects fascinating.

Student's curiosity will influence the competences they acquire. Personal improvement has a greater impact on the development of competences than extrinsic motivations. As indicated by [35] (p. 4):

“Goals oriented towards developing competences (i.e., towards dominating a specific field of activity or knowledge) place more value on the personal improvement that can be achieved through the activity than the results that can be evaluated by external criteria. This explains 
their stronger relationship with an intrinsic motivation (by the action in itself), than with an extrinsic motivation (the means to reach another goal)".

Curiosity can be considered as a affective personality dimension of learning [36] and as [33] points out "Among other adaptive outcomes, curiosity is suspected to play a role in the development of intelligence, wisdom, happiness, meaning in life, distress tolerance, and satisfying and engaging social relationships" (p. 988).

\subsection{Potential Moderators: Effort and Relationship with the Tutor}

Assuming that the proposed relationships are not free from the influences of the learning context, we selected two potential moderators who, due to their prominence in previous studies [35], could provide an alternative model: (1) the degree of effort perceived by the student and (2) the intensity of their personal interaction with their tutor.

The sensation of uncertainty derived from the methodology of the subject implies, on the one hand, a methodology unlike those the students have become familiar with over the course of their studies (more autonomous and complex), and on the other, tutorial support of an unknown kind, placing students in a new situation. Once the project is complete, many students feel that the effort required has been excessive and generally feel less satisfied. The study by [37] coincides with this result, where the students who were less satisfied with the methodology used in skills training were those who expected to obtain better results, partly motivated by the effort they had to make in order to obtain the expected grade. In other words, at the same level of perception of skills achieved, students who believe they have made less effort are more satisfied, whilst satisfaction is lower amongst those who feel that they have made more effort. This is coherent with a cost/benefit perspective, or a utilitarian attitude towards the project.

The moderating effect of the intensity of the personal relationship with the tutor is much more apparent. A good relationship with the tutor, which continues over time and at a profound level, favours the satisfaction perceived by students [38,39]. Tutor support has been shown to be a precedent for student satisfaction [40], as students experience insecurity when faced with a task requiring a high degree of autonomy such as the UD [41]. In this sense, the tutor plays a fundamental role, even if it is limited to providing students with resources such as guidelines for quoting references, websites or specific online courses, amongst others. It is very likely that their involvement in the proposed relationships is important, in as much as both the acquisition of skills and their final satisfaction are likely to be conditioned by (1) the sensation of security derived from the tutor's involvement in the various stages of the project, and (2) students' assessment of their final performance.

A learning process that is personally supported by a tutor is perceived by students as being more solid and secure, and generates the same security in the acquisition of skills and the resulting satisfaction [42]. Furthermore, interaction between teachers and students is an important indicator of system quality [43].

\section{Materials and Methods}

\subsection{Idenfication of Hypotheses and Suggested Model}

The aim of our research is to analyse the following sequence: perception of acquired skills $\rightarrow$ perceived utility $\rightarrow$ overall satisfaction. This sequence is used to evaluate the potential effects of students' attitudes regarding their intellectual curiosity in general, and their motivation with regard to the UD in particular. We also understand that the series of relationships analysed does not stand apart from other factors, and therefore efforts have been made to identify those that could affect them by acting as moderators, namely the relative effort required to pass the subject, and the amount of personal contact with the tutor.

We propose the following hypotheses: 
- H1: The perception of skills achieved by students as a result of writing their UD predict satisfaction directly (H1a) and indirectly through utility (H1b).

- $\quad$ H2: Students' intellectual curiosity predicts skill acquisition directly (H2a) and indirectly through motivation $(\mathrm{H} 2 \mathrm{~b})$.

- H3: Effort moderates the relationship between perception of acquired skills and satisfaction.

- H4: The personal relationship with tutors moderates the relationship between perception of acquired skills and satisfaction.

Having reviewed the respective literature and the hypotheses we have established, we propose the causal model $\left(\mathrm{M}_{\mathrm{T}}\right)$ shown in Figure 1 for the study and analysis.

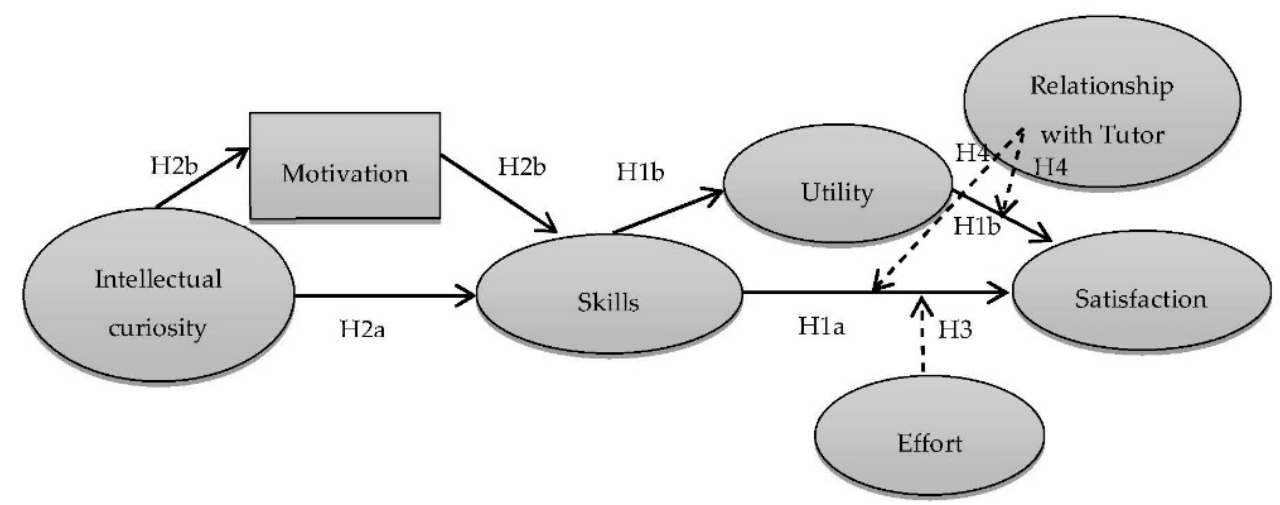

Figure 1. Suggested model. (Source: authors' own).

\subsection{Data Collection}

In order to contrast these hypotheses, we consulted all those students who presented their UD during the academic year 2013-2014 in the two degree courses-in Economics and Business Studies-taught at the Faculty of Economic and Business Sciences of the University of Santiago de Compostela, Spain.

The UD for these courses is a subject worth six European Credit Transfer System credits, representing approximately 150 hours' work by the student. The student has a tutor throughout the process. The faculty assigns the topic (with which a tutor is associated) based on the students' academic record. The UD is assessed entirely by an examining board. Tutors do not sit on this board, although they are required to draw up a report.

A self-administered questionnaire was completed by the students and returned with their dissertation. The target population was the 172 students who presented their UD during the academic year 2013-2014. Approximately $75.7 \%$ of the 172 students answered the survey, comprising a total of 130 valid questionnaires. Despite the lack of consensus, it seems that a response rate of over $50 \%$ can be considered acceptable [44]. It represents a sample error of $4.3 \%$ considering a maximal variance with $\mathrm{p}=\mathrm{q}=0.5$ and a level of confidence of $95 \%$. Of the 130 questionnaires, 70 were answered by females (53.4\%) and 60 by males (45.8\%). All the respondents were fourth-year (almost 24 years old), full-time, undergraduate students. Only $13 \%$ were resit students and $74 \%$ presented their project in the July session, and the remainder in September.

\subsection{Measurement of Latent Variables}

In order to measure the latent variables of personality-intellectual curiosity and motivation-and attitude-sensation of having acquired skills, on the utility of the subject and the satisfaction obtained-Likert 5-point scales were used. The questionnaire based on a review of existing literature and on consultation with experts. The survey instrument was revised and finalized in accordance with feedback from a pilot sample of 15 students in academic year 2012-2013. 
The indicators form a part of a wider-ranging survey on the competences, perception of skills acquisition and satisfaction with the UD. When designing the questionnaire, items regarding the perception of acquired skills were based on the generic skills to be achieved in the degree. In general, satisfaction can be measured from a global perspective (overall satisfaction) or by analysing the satisfaction with different attributes (attribute satisfaction). Overall satisfaction and attribute satisfaction are distinct but related constructs [45]. It has been proven that attribute satisfaction has significant effects on overall satisfaction [46]. In our case, we analysed satisfaction with the information, the virtual classroom, the evaluation system and the teaching-learning method related to UD. The indicators used to approximate intellectual curiosity are adaptations of the Curiosity and Exploration Inventory-II scale (IEC-II) [33] and of the Need for Cognition, (NFC) [47] adapted by [48]. Students were also asked about the degree of motivation and the utility they expect from the end of degree work.

The following dichotomous variables were used as moderators: relative effort (sensation of more or less effort than that required to pass other subjects on the degree course), and the intensity of personal contact with the tutor (more or fewer meetings with the tutor than the mean for the sample). Table 1 shows the indicators used for this project.

Table 1. Measurement of latent variables.

\begin{tabular}{|c|c|}
\hline Measurement & Construct \\
\hline $\begin{array}{l}\text { The complex problems attract me than simple ones (NEED1) } \\
\text { For me, thinking is fun (NEED2) } \\
\text { I enjoy thinking and reflection (NEED3) } \\
\text { I prefer a difficult, important intellectual task over one that does not require much thought, } \\
\text { whether it's important or not (NEED4) }\end{array}$ & $\begin{array}{l}\text { Intellectual } \\
\text { curiosity }\end{array}$ \\
\hline Overall, my motivation when completing the UD was good (MOTGLOB) & Motivation \\
\hline $\begin{array}{c}\text { Being able to define the objectives of the project (SKILL1) } \\
\text { Being able to organise the project (SKILL2) } \\
\text { Knowing how to look for relevant information (SKILL3) } \\
\text { Using knowledge I acquired during my studies (SKILL4) } \\
\text { Being able to organise the information (SKILL5) } \\
\text { Identifying the limitations of my project (SKILL6) } \\
\text { Developing my research abilities (SKILL7) } \\
\text { Developing my working capacity (SKILL8) } \\
\text { Developing my ability to manage information (SKILL9) } \\
\text { Improving my ability to define problems (SKILL10) } \\
\text { Improving my ability to solve problems and make decisions (SKILL11) } \\
\text { Improving my ability to analyse and summarise data (SKILL12) } \\
\text { Improving my ability to work autonomously (SKILL13) } \\
\text { Improving my ability to properly present the results in writing (SKILL14) }\end{array}$ & Skills \\
\hline $\begin{array}{l}\text { I think that the UD has a real use in the world of business (REALUTIL) } \\
\text { I think that the UD provided me with important training for my professional career (FUTURUTIL) } \\
\text { The learning method reinforced my knowledge about other subjects on the degree course } \\
\text { (REINFORCEUTIL) }\end{array}$ & Utility \\
\hline $\begin{array}{l}\text { Overall I am satisfied with the information I received about the UD (SAT1) } \\
\text { Overall I am satisfied with the evaluation system used (SAT2) } \\
\text { Overall I am satisfied with the virtual classroom for the subject (SAT3) } \\
\text { Overall I am satisfied with the teaching-learning method used (SAT4) }\end{array}$ & Satisfaction \\
\hline
\end{tabular}

Source: authors' own, based on the questionnaire.

\section{Results}

The descriptive analyses were obtained using the statistics package IBM SPSS Statistics 20. To contrast the hypotheses, a structural equation model was estimated using the IBM program SPSS Amos 21. 


\subsection{Descriptive Analysis}

The statistics for the observable variables from the model have relatively high mean values: they are higher in the assessment of the skills acquired, and lower in the perceived utility. The values obtained indicate that the skills focused on developing the capacity to work, carry out research and autonomy are those that the students achieve largely during the process of completing their UD. This is an aspect that should be perceived by students as extremely useful in terms of their future careers; however, the utility score of the UD for their professional development is lower than expected. Nevertheless, it is important to consider that their lack of experience in the job market may affect their expectations in this regard.

It should be noted that although the students have a positive perception of the level of skills acquired (all of the mean values are higher than 3.3), one of the least valued is the use of the skills acquired in their studies (SKILL4). Moreover, in terms of the perceived utility, the variable for which the lowest mean score is obtained (2.7) is utility in relation to reinforcement of other subjects (REINFORCEUTIL). These results may be due to the process of assigning topics and tutors, as on the one hand the topics offered focus on specific subjects from the degree course, and on the other, the assignation process is competitive, so that students with a poorer academic record have fewer possibilities of selecting topics they find more interesting. These issues could be overcome in degree courses where there is a smaller student/professor ratio, meaning that the process is simpler, as it allows students to propose their topic or interest and select a tutor to guide them.

In general, satisfaction with the UD was positive; the question here is to determine how the skills acquired and perceived utility are important in this sense, and to what extent students' intellectual curiosity and motivation, which have high mean values, can affect this model. Table 2 summarizes the results.

Table 2. Descriptive statistics.

\begin{tabular}{cccccc}
\hline & $\mathbf{N}$ & Mean & Standard dev. & Skewness & Kurtosis \\
\hline NEED1 & 130 & 3.531 & 1.0130 & -0.400 & -0.130 \\
NEED 2 & 130 & 3.746 & 0.8099 & -0.212 & -0.419 \\
NEED 3 & 130 & 3.162 & 0.9709 & 0.030 & -0.275 \\
NEED 4 & 130 & 3.615 & 0.9756 & -0.277 & -0.466 \\
MOTIVATION & 130 & 3.415 & 1.0251 & -0.596 & -0.131 \\
SKILL1 & 125 & 3.680 & 0.9123 & -0.686 & 0.627 \\
SKILL2 & 125 & 3.688 & 0.9018 & -0.755 & 0.782 \\
SKILL3 & 124 & 3.758 & 0.9574 & -0.635 & 0.377 \\
SKILL4 & 123 & 3.382 & 1.0043 & -0.293 & -0.093 \\
SKILL5 & 122 & 3.746 & 0.9232 & -0.638 & 0.686 \\
SKILL6 & 124 & 3.685 & 0.9907 & -0.563 & 0.038 \\
SKILL7 & 130 & 3.885 & 0.9033 & -0.534 & -0.124 \\
SKILL8 & 130 & 3.977 & 0.9019 & -0.657 & 0.034 \\
SKILL9 & 130 & 3.731 & 0.9628 & -0.647 & 0.378 \\
SKILL10 & 130 & 3.377 & 0.9002 & -0.559 & 0.620 \\
SKILL11 & 130 & 3.469 & 0.9416 & -0.612 & 0.729 \\
SKILL12 & 130 & 3.815 & 0.8786 & -0.599 & 0.450 \\
SKILL13 & 130 & 3.831 & 1.0502 & -0.871 & 0.482 \\
SKILL14 & 130 & 3.346 & 1.0617 & -0.336 & -0.437 \\
REALUTIL & 130 & 2.900 & 1.1604 & -0.074 & -0.800 \\
FUTURUTIL & 130 & 2.946 & 1.1019 & -0.208 & -0.743 \\
REINFORCEUTIL & 130 & 2.700 & 1.1657 & 0.070 & -1.003 \\
SAT1 & 130 & 3.262 & 1.0823 & -0.093 & -0.891 \\
SAT2 & 130 & 3.154 & 0.9762 & -0.212 & -0.469 \\
SAT3 & 130 & 3.285 & 1.0728 & -0.093 & -0.891 \\
SAT4 & 130 & 3.085 & 0.9886 & -0.316 & -0.207 \\
\hline
\end{tabular}


Normality was checked with SPSS and AMOS. A number of authors argue that the values for asymmetry and kurtosis between -2 and +2 are considered acceptable in order to prove normality [49-51]. In our case, the values for Skewness ranged from -0.9 to 0.1 and kurtosis ranged from -1 to 0.8 which suggests a normal distribution of the variables observed.

\subsection{Measurement Model}

Three indicators were used to assess reliability of the constructs considered in this study: Cronbach's alpha, variance extracted and composite reliability. The first analysis was conducted with the statistics programme IBM SPSS Statistics 20, while for the last two a confirmatory model was estimated, entering all of the constructs simultaneously.

The confirmatory factorial analysis (CFA) was carried out using the programme IBM SPSS Amos 21 and maximum likelihood. The results, shown in Table 3, indicate acceptable values, with the sole exception of the variance extracted from the intellectual curiosity construct, which is below the recommended level (0.5). Nevertheless, considering the values of the rest of the reliability indicators, we decided to maintain it.

Table 3. Reliability and convergent validity of the constructs.

\begin{tabular}{|c|c|c|c|c|c|}
\hline Construct & Indicators & $\begin{array}{c}\text { Factor } \\
\text { Loadings }\end{array}$ & $\begin{array}{c}\text { Cronbach's } \\
\text { Alpha }\end{array}$ & $\begin{array}{l}\text { Composite } \\
\text { Reliability }\end{array}$ & $\begin{array}{l}\text { Variance } \\
\text { Extracted }\end{array}$ \\
\hline \multirow{4}{*}{$\begin{array}{l}\text { Intellectual } \\
\text { curiosity }\end{array}$} & NEED1 & 0.59 & \multirow{4}{*}{0.74} & \multirow{4}{*}{0.75} & \multirow{4}{*}{0.44} \\
\hline & NEED2 & 0.769 & & & \\
\hline & NEED3 & 0.741 & & & \\
\hline & NEED4 & 0.513 & & & \\
\hline \multirow{14}{*}{ Skills } & SKILL1 & 0.739 & \multirow{14}{*}{0.94} & \multirow{14}{*}{0.94} & \multirow{14}{*}{0.51} \\
\hline & SKILL2 & 0.7 & & & \\
\hline & SKILL3 & 0.629 & & & \\
\hline & SKILL4 & 0.635 & & & \\
\hline & SKILL5 & 0.678 & & & \\
\hline & SKILL6 & 0.662 & & & \\
\hline & SKILL7 & 0.683 & & & \\
\hline & SKILL8 & 0.755 & & & \\
\hline & SKILL9 & 0.743 & & & \\
\hline & SKILL10 & 0.796 & & & \\
\hline & SKILL11 & 0.753 & & & \\
\hline & SKILL12 & 0.756 & & & \\
\hline & SKILL13 & 0.778 & & & \\
\hline & SKILL14 & 0.685 & & & \\
\hline \multirow{3}{*}{ Utility } & REALUTIL & 0.923 & \multirow{3}{*}{0.84} & \multirow{3}{*}{0.85} & \multirow{3}{*}{0.65} \\
\hline & FUTURUTIL & 0.851 & & & \\
\hline & REINFORCEUTIL & 0.622 & & & \\
\hline \multirow{4}{*}{ Satisfaction } & SAT1 & 0.795 & \multirow{4}{*}{0.81} & \multirow{4}{*}{0.84} & \multirow{4}{*}{0.50} \\
\hline & SAT2 & 0.724 & & & \\
\hline & SAT3 & 0.587 & & & \\
\hline & SAT 4 & 0.513 & & & \\
\hline
\end{tabular}

Source: authors' own, based on the questionnaire.

Table 3 also shows the presence of convergent validity in all of the constructs, as all of the factorial loadings are substantial (higher than 0.5$)$ and significant $(p<0.05)$.

The discriminant validity was verified using two procedures. Firstly, the confidence intervals were calculated for the relationships between latent variables, ensuring that they did not include the unit (Table 4). Secondly, the correlation square between constructs was calculated, and compared with the variance extracted from the component constructs of each pair. Both procedures coincided in demonstrating the existence of discriminant validity between pairs of constructs. 
Table 4. Discriminant validity between pairs of constructs.

\begin{tabular}{cccccc}
\hline Constructs & Correlation & Error & $\mathbf{( x ,}$ & $, \mathbf{x})$ & Correlation $^{\mathbf{2}}$ \\
\hline Skills-Utility & 0.699 & 0.089 & 0.873 & 0.525 & 0.488601 \\
Utility-Satisfaction & 0.652 & 0.103 & 0.854 & 0.450 & 0.425104 \\
Skills-Satisfaction & 0.711 & 0.07 & 0.848 & 0.574 & 0.505521 \\
Intellectual curiosity-skills & 0.442 & 0.05 & 0.540 & 0.344 & 0.195364 \\
Intellectual curiosity-Utility & 0.377 & 0.076 & 0.526 & 0.228 & 0.142129 \\
Intellectual curiosity-Satisfaction & 0.349 & 0.057 & 0.461 & 0.237 & 0.121801 \\
Skills-Utility & 0.699 & 0.089 & 0.873 & 0.525 & 0.488601 \\
\hline
\end{tabular}

Source: authors' own, based on the questionnaire.

\subsection{Structural Analysis}

The proposed theoretical model $\left(\mathrm{M}_{\mathrm{T}}\right)$ was compared with a series of nested competing models. The objective was to determine the best fitting model from a set of models. In this study, three alternative models were proposed: $\mathrm{M}_{1}, \mathrm{M}_{2}$ and $\mathrm{M}_{3}$. $\mathrm{M}_{1}$ removes the path between "Intellectual curiosity" and "Skills". $\mathrm{M}_{2}$ removes the path between "Skills" and "Satisfaction". Finally, $\mathrm{M}_{3}$ removes the path between "Intellectual curiosity" and "Skills" and between "Skills" and "Satisfaction". The sequential Chi-square $\left(\chi^{2}\right)$ difference tests were performed to assess whether there were significant differences in estimated construct covariance explained by the four structural models $[52,53]$. The $\chi^{2}$ difference test between $\mathrm{M}_{\mathrm{T}}$ and $\mathrm{M}_{1}\left(\Delta \chi^{2}=13.76 ; \Delta \mathrm{df}=1\right)$ suggested that $\mathrm{M}_{\mathrm{T}}$ was performing significantly better than $\mathrm{M}_{1}$. The $\chi^{2}$ difference test between $\mathrm{M}_{\mathrm{T}}$ and $\mathrm{M}_{2}\left(\Delta \chi^{2}=18.43 ; \Delta \mathrm{df}=1\right)$ suggested that $\mathrm{M}_{\mathrm{T}}$ was performing significantly better than $\mathrm{M}_{2}$. Finally the $\chi^{2}$ difference test between $\mathrm{M}_{\mathrm{T}}$ and $\mathrm{M}_{3}\left(\Delta \chi^{2}=31.91\right.$; $\Delta d f=2)$ suggested that $M_{T}$ was performing significantly better than $M_{3}$. The results of the difference tests favoured the proposed theoretical model $\mathrm{M}_{\mathrm{T}}$ to the alternatives models.

A comparison of a set of goodness-of-fit measures reveals that the fit indices are very similar and acceptable [54-56]. Table 5 shows the fit indices of four models. The goodness-of-fit measures are slightly better for the theoretical model $\mathrm{M}_{\mathrm{T}}$ than the competing ones. It was therefore concluded that the theoretical model $\mathrm{M}_{\mathrm{T}}$ could be retained.

Table 5. Fit indices for competing models.

\begin{tabular}{ccccc}
\hline & Theoretical $\left(\mathbf{M}_{\mathbf{T}}\right)$ & $\mathbf{M}_{\mathbf{1}}$ & $\mathbf{M}_{\mathbf{2}}$ & $\mathbf{M}_{\mathbf{3}}$ \\
\hline Chi-square (CMIN) & 471.222 & 484.978 & 489.652 & 503.130 \\
Degrees of freedom (df) & 288 & 289 & 289 & 290 \\
CMIN/df & 1.636 & 1.678 & 1.694 & 1.735 \\
CFI & 0.901 & 0.896 & 0.894 & 0.887 \\
RMSEA & 0.070 & 0.072 & 0.073 & 0.075 \\
\hline
\end{tabular}

Source: authors' own.

The overall model indicates that $\chi^{2}$ is 471.22 with 288 degrees of freedom (d.f.) $(p<0.0001)$. Technically, the p-value should be greater than 0.05 , i.e., statistically insignificant but in practice, as stated [56] "the $\chi^{2}$-value is very sensitive to sample size and frequently results in the rejection of a well-fitting model". In our case, the sample size was limited by the population size itself; 172 students who presented their UD during the academic year 2013-2014.

The quotient between the $\chi^{2}$ and the degrees of freedom (d.f.) was 1.64. An acceptable adjustment is considered if this index is less than 3 [55]. The RMSEA was 0.07. In this sense, index values under 0.8 are recommended [57]. The CFI was 0.90 equal to the reference value for an acceptable adjustment [54].

The regression coefficients $(\beta)$ shown in Figure 2 allow for the verification of hypotheses 1 to 5 . All coefficients are statistically significant, thereby confirming the importance of both the perceived utility and the perception of achieved skills in terms of students' satisfaction with their UD. We also 
confirmed that skill acquisition is decisive for the UD to be perceived as useful, as this coefficient scored the highest value. The results also confirm our hypotheses ( $\mathrm{H} 2$, a and b) that students' skill acquisition depends on their intrinsic characteristics, i.e., their own attitude towards tasks requiring intellectual effort and their motivation for completing the UD, which in turn is affected by this intellectual curiosity.

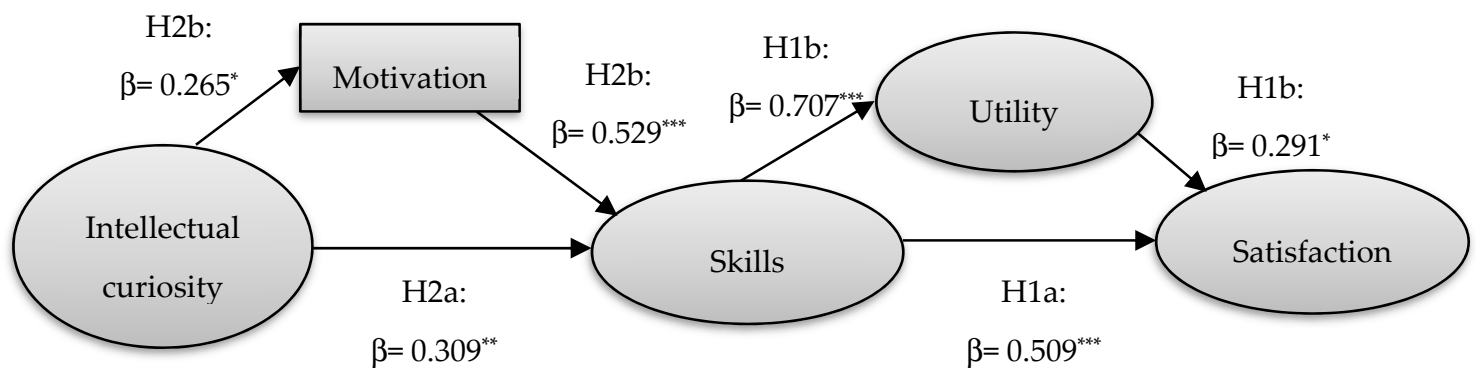

Figure 2. SEM results. ${ }^{*} p<0.05 ;{ }^{* *} p<0.01 ;{ }^{* * *} p<0.001$. (Source: authors' own).

Table 6 illustrates the direct and indirect effects between the various constructs. The total effect of intellectual curiosity on perception of acquired skills was found to be $0.450: 0.141$ directly and 0.309 indirectly. The total effect of the perception of acquired skills on satisfaction was found to be 0.715 : 0.509 directly and 0.206 indirectly. This indicates that the perception of acquired skills is the most important variable that influences students' satisfaction with UD.

Table 6. Direct, indirect and total effect.

\begin{tabular}{cccc}
\hline & Direct Effect & Indirect Effect & Total Effect \\
\hline Intellectual & 0.265 & 0.000 & 0.265 \\
curiosity $\rightarrow$ Motivation & 0.529 & 0.000 & 0.529 \\
Motivation $\rightarrow$ Skills & 0.141 & 0.309 & 0.450 \\
Intellectual curiosity $\rightarrow$ Skills & 0.707 & 0.000 & 0.707 \\
Skills $\rightarrow$ Utility & 0.291 & 0.000 & 0.291 \\
Utility $\rightarrow$ Satisfaction & 0.509 & 0.206 & 0.715 \\
Skills $\rightarrow$ Satisfaction &
\end{tabular}

Source: compiled by the author, based on the questionnaire.

Having estimated the base model and tested the initial hypotheses, we then tested the effect of the variables proposed as moderators.

Firstly, the base model was evaluated for two groups of students: those who had made a greater effort with the subject than with the other subjects on the degree course (102 students stated that they had already dedicated to UD "more" and "much more" effort than the other subjects), and the remainder (28 students stated that they had already dedicated to UD "equal" or "less" effort). For each of the regressions, the restricted model was compared with the model that releases its parameter in both groups. The results show that the effect on satisfaction of perception of acquired skills by students is significantly different in both groups: in the group of students who indicated that they had made a relatively greater effort, the effect is weaker $(b=0.495$ compared to $b=0.812)$.

Secondly, we evaluated the moderating effect of the intensity of the personal contact between the student and his tutor. We considered two groups. A group of students who maintained a more intense relationship with the tutor and the others. The first group comprised 34 who met with their tutor on seven or more occasions. The second group consisted of 96 students who met less than 7 times with their tutor. Two significant differences were observed. The first referred to the perceived utility in comparison to the declared satisfaction: although the relationship is significant in both groups, it is significantly stronger for the students who had a more intense personal relationship with their tutors $(b=0.609$ compared to $b=0.494)$. The relationship between skills and satisfaction also proved to be 
significantly stronger for the students who had more personal contact with their tutors. In this group, the relationship between skills and satisfaction is positive and significant $(b=0.430 ; p<0.05)$, which is not the case for the students who had fewer personal tutorials.

In summary, the relationship subject to more moderating factors is that defined by the perception of skills achieved by the students, and the satisfaction that they obtain from them. The perceived relative effort perceived and the intensity of personal contact with the tutor strengthens this relationship. Students who perceived greater relative effort and had more opportunities for personal contact with their tutors claim to have higher levels of satisfaction because of the perception of skills acquired.

\section{Discussion and Conclusions}

The main contribution of this study is to explore in depth the chain of causal relationships that ensue in students' satisfaction. A number of studies have explored one or several of these factors, but none have examined them as a whole [19]. The ability to simultaneously analyse these relationships is one of the benefits of the structural equation method, which is also suitable for dealing with latent variables. By using this tool we have been able to confirm, as expected, that the perception of acquired skills are in themselves a source of students' satisfaction, but also in terms of their utility for the future. The perception of acquired skills by university students should serve to help them find employment. In practice, studies such as those by [58], or those of [59] reveal a discrepancy between the skills acquired by graduates and those required by employers. The results indicate that the closer the perceived acquired skills approach their expectations, in terms of their repercussion on a future career, the greater the perceived utility, and therefore the higher the students' satisfaction levels.

The prominence of the acquired skills justifies the interest in their background. The intellectual curiosity of students is at their root per se and because of their influence on the motivation regarding the subject that they have declared. This explains the prominence of the skills acquired, although they are spurred by the future utility attributed to them, supported by elements of personality and motivation that facilitate their acquisition.

It is also important to note that hypothesis tests were carried out for all possible relationships between the variables from the proposed model. Those presented, and which respond to the initial hypotheses, are confirmed by the data. This methodology provides additional information that is worthy of comment. The potential relationships between the initial variables of the model (intellectual curiosity and students' motivation) and the final variables (perceived utility and satisfaction) are not supported by the data. The study by [60] coincides with this result, indicating that students' expectations with regard to intellectual matters have little influence on their satisfaction. However, Ref. [61] maintain that motivation and utility are the two aspects responsible for students' satisfaction. In our case, the effect of motivation on satisfaction is not direct, but instead is produced through the perception of skills acquisition.

Previous studies have concluded that students' attitude towards the role of the tutor conditions skill acquisition, but as can be deduced from the model we tested, although this attitude does not directly influence their satisfaction, it does have indirect effects on it, derived from its influence on the skills that are developed [38]. Our study also confirmed the importance of the tutor, in line with the findings of the study by [62]. Their presence -in this case, their physical presence- throughout the process of completing the UD strengthens the central relationships of the model. Faced with equal skills perception, students who had more personal contact with their tutors expressed greater satisfaction. We maintain that the reason for this is the sensation of security regarding the skills acquired, and the resulting increase in satisfaction. The results coincide with those from previous research, in which the role of the tutor is emphasized in performing a dual, pedagogical and psychological role. In the study by [63], reference is made to this dual role and with regard to functions of a psychological nature, highlighting the role of the tutor in terms of getting students' attention and interest, encouraging them and providing a sense of security. 
Lastly, another moderating element has been demonstrated that underlies the relationship between the perception of the skills acquired and satisfaction with the subject: the relative effort perceived by the students. At the same levels of the perception of the acquired skills, students who have perceived a lower relative effort are more satisfied. The cost/benefit evaluation must lie at the root of this phenomenon. Given the same benefit, the greater the satisfaction the lower the cost. It is important to note that effort has been measured in relation to the effort put into passing other subjects on the degree course, and that it has been included in the analysis by dividing the sample into two groups: those who have made a greater effort than with other subjects, and those who have made an equal or lesser effort. We consider that if an absolute and objective indicator of the effort had been used, the results would have been the same.

Ultimately, based on the model presented in this paper, the following conclusions can be reached. Firstly, we have verified the importance of perceived utility and skills achieved on satisfaction with the UD, and that skill acquisition is decisive in order for it to be perceived as useful. Secondly, the results corroborate that skill acquisition by students depends on their intrinsic characteristics, i.e., their own attitude towards tasks that require intellectual effort and the motivation to develop this material, which in turn is affected by this intellectual curiosity. Thirdly, the students who perceived a greater effort obtained higher levels of satisfaction with the acquired skills. Finally, the relationship between the perception of acquired skills and satisfaction proved to be significantly stronger amongst students who had more personal contact with their tutors.

Our work has a series of limitations which could potentially be corrected in future research. Firstly, the sample size should be increased to include the opinions of students who will submit their UDs in the future. This will allow for the analysis of the differences and impact of other moderating variables such as gender and degree course. A second point of interest would be the future use of questionnaires applied to closer cultural contexts, such as those conducted by (8). Thirdly, in-depth interviews could be held with students in order to obtain a more accurate insight into their opinions regarding the constructs analysed. Finally, and looking ahead to the future, it would be both interesting and necessary to extend this line of research to other faculties and universities, involving other researchers or even creating research networks associated with this subject. In any event, the extent of this process will be conditioned by the characteristics and degree of similarity between the management protocols for the UD subject in the various faculties.

Author Contributions: Conceptualization, F.M.-R., P.F.E. and E.V.-R.; methodology, F.M.-R., P.F.E. and E.V.-R.; formal analysis, F.M.-R., P.F.E. and E.V.-R.; investigation, F.M.-R., P.F.E. and E.V.-R.; data curation, F.M.-R., P.F.E. and E.V.-R.; writing-original draft preparation, F.M.-R., P.F.E. and E.V.-R.; writing-review and editing, F.M.-R., P.F.E. and E.V.-R.; supervision, F.M.-R.; project administration, F.M.-R., P.F.E. and E.V.-R. All authors have read and agreed to the published version of the manuscript.

Funding: This research received no external funding.

Conflicts of Interest: The authors declare no conflict of interest.

\section{References}

1. Gairín, J.; Feixas, M.; Guillamón, C.; Quinquer, D. La tutoría académica en el escenario europeo de la Educación Superior. Rev. Inter. Form. Prof. 2004, 18, 61-77.

2. Duzevic, I.; Casni, A.C. Student and faculty perceptions of service quality: The moderating role of the institutional aspects. High. Educ. 2015, 70, 567-584. [CrossRef]

3. González-Peiteado, M.; Pino-Juste, M.; Penado, M. Estudio de la satisfacción percibida por los estudiantes de la UNED con su vida universitaria. RIED 2017, 20, 243-260. [CrossRef]

4. Tuning Proyect. An Introduction to Tuning Educational Structures in Europe. Available online: http: //www.unideusto.org/tuningeu/images/stories/documents/General_Brochure_Spanish_version.pdf (accessed on 6 June 2016).

5. Zamora, F.; Sánchez, J. Los Trabajos de Fin de Grado: Una herramienta para el desarrollo de competencias transversales en la educación superior. REDU 2015, 13, 197-211. [CrossRef] 
6. Villarejo, A.F.; Peral, B.; Sánchez, M.J. Antecedentes en la Satisfacción y el Desarrollo de Competencias del Estudiante de Grado. In Bases Para Emprender y Gestionar con Racionalidad Económica y Transparencia; Guerrero, F.P., Díaz, D.C., Eds.; University of Málaga: Málaga, Spain, 2013.

7. Engström, H. A model for conducting and assessing interdisciplinary undergraduate dissertations. Assess. Eval. High. Educ. 2014, 40, 725-739. [CrossRef]

8. Webster, F.; Pepper, D.; Jenkins, A. Assessing the Undergraduate Dissertation. Assess. Eval. High. Educ. 2010, 25, 71-80. [CrossRef]

9. Lent, R.W.; Brown, S.D.; Hackett, G. Toward a unifying social cognitive theory of career and academic interest, choice, and performance. J. Vocat. Behav. 1994, 45, 79-122. [CrossRef]

10. Lent, R.W. Toward a Unifying Theoritical nd Practical Perspective on Well-Being and Psychosocial Adjustment. J. Counc. Psychol. 2004, 51, 482-509. [CrossRef]

11. Lent, R.W.; Taveira, M.C.; Sheu, H.B.; Singley, D. Social cognitive predictor of academic adjustment and life satisfaction in Portuguese colleges students: A longitudinal analysis. J. Vocat. Behav. 2009, 74, 190-198. [CrossRef]

12. Brown, S.D.; Tramaine, S.; Hoxha, D.; Telander, K.; Fan, X.; Lent, R.W. Social cognitive predictors of college students'academic performance and persistence: A meta-analytic path analysis. J. Vocat. Behav. 2008, 72, 298-308. [CrossRef]

13. Boerchi, D.; Magnano, P.; Lodi, E. Development and preliminary validation of the college competencies scale. Curr. Psychol. 2018. [CrossRef]

14. Magnano, P.; Lodi, E.; Boerchi, D. The Role of Non-intellective Competences and Performance in College Satisfaction. Interchange 2020. [CrossRef]

15. Lodi, E.; Boerchi, D.; Magnano, P.; Patrizi, P. College Satisfaction Scale (CSS): Evaluation of contextual satisfaction in relation to college student life satisfaction and academic performance. Appl. Psychol. Bull. 2017, 55, 51-64.

16. Helgesen, Ø.; Nesset, E. Images, satisfaction and antecedents: Drivers of student loyalty? A case study of a Norwegian university college. Corp. Reput. Rev. 2007, 10, 38-59. [CrossRef]

17. Díaz, R.; Freire, M.P.; Martínez, F.; Maside, J.M.; Vázquez, E. Grado de satisfacción de los estudiantes en la elaboración y defensa de los Trabajos de Fin de Grado en Economía de la Universidad de Santiago de Compostela. In Investigaciones en el Contexto Universitario Actual; Membiela, P., Casado, N., Cebreiros, M.I., Eds.; Educación Editora: Ourense, Spain, 2014; pp. 227-231.

18. Gil, P.; Ibáñez, A. Percepción de utilidad y grado de satisfacción del alumnado de formación del profesorado con el Método de Caso. Aula Abierta 2013, 41, 79-90.

19. López, M.V.; Pérez, M.C.; Rodríguez, L. Aplicación del aprendizaje combinado en contabilidad. Un análisis comparativo entre diferentes titulaciones universitarias. Rev. Educ. 2013, 60, 461-482.

20. Todd, M.; Bannister, P.; Clegg, S. Independent inquiry and the undergraduate dissertation: Perceptions and experiences of final-year social science students. Assess. Eval. High. Educ. 2004, 29, 335-355. [CrossRef]

21. Jaldemark, J.; Lindberg, J.O. Technology-mediated supervision of undergraduate students' dissertations. Stud. High. Educ. 2013, 38, 1382-1392. [CrossRef]

22. Greenbank, P.; Penketh, C. Student autonomy and reflections on researching and writing the undergraduate dissertation. J. Furth. High. Educ. 2009, 33, 463-472. [CrossRef]

23. De Kleijn, R.A.; Mainhard, M.T.; Meijer, P.C.; Brekelmans, M.; Pilot, A. Master's thesis project: Students perceptions of supervisor feedback. Assess. Eval. High. Educ. 2013, 38, 1012-1026. [CrossRef]

24. Pyhältö, K.; Vekkaila, J.; Keskinen, J. Exploring the fit between doctoral students and supervisors perceptions of resources and challenges vis-à-vis the doctoral journey. Int. J. Dr. Stud. 2012, 7, 395-414.

25. Chiva, I.; Ramos, G.; Moral, A. Análisis de la satisfacción de los estudiantes del grado de Pedagogía de la Universitat de València. Rev. Complut. Educ. 2017, 28, 755-772.

26. González, M.M.; Sanchís, C. Satisfacción de los egresados con la formación recibida en el Máster de Estudios Avanzados en Dirección de Empresas. Rev. Educ. Cont. Fin. Adm. Empresas 2014, 5, 33-48.

27. Yin, H.; Wang, W.; Han, J. Chinese undergraduates' perceptions of teaching quality and the effects on approaches to studying and course satisfaction. High. Educ. 2016, 71, 39-57. [CrossRef]

28. Zhou, J.; Cole, D. Comparing international and American students: Involvement in college life and overall satisfaction. High. Educ. 2016, 73, 655-672. [CrossRef] 
29. Suldo, S.M.; Mihalas, S.T.; Powell, H.A.; French, R.B. Ecological predictors of substance use in middle school students. Sch. Psychol. Q. 2008, 23, 373-388. [CrossRef]

30. Bailey, T.H.; Phillips, L.J. The influence of motivation and adaptation on student's subjective well-being, meaning in life and academic performance. High. Educ. Res. Dev. 2016, 35, 201-216. [CrossRef]

31. Crowe, J.; Boe, A. Integrating Undergraduate Research into Social Science Curriculum: Benefits and Challenges of Two Models. Educ. Sci. 2019, 9, 296. [CrossRef]

32. Stolk, J.; Harari, J. Student motivations as predictors of high-level cognitions in project-based classrooms. Act. Learn. High. Educ. 2014, 15, 231-247. [CrossRef]

33. Kashdan, T.B.; Gallagher, M.W.; Silvia, P.J.; Beate, P.; Winterstein, B.P.; Breen, W.E.; Terhar, D.; Steger, M.F. The curiosity and exploration inventory-II: Development, factor structure, and psychometrics. J. Res. Pers. 2009, 43, 987-998. [CrossRef]

34. Peterson, C.; Park, N. Classification and measurement of character strengths: Implications for practice. In Positive Psychology in Practice; Linley, P.A., Joseph, S., Eds.; John Wiley \& Sons: New York, NY, USA, 2004; pp. 433-446.

35. Lucas, S. Desarrollo de las competencias "preocupación por la calidad" y la "motivación de logro" desde la docencia universitaria. REDU 2007, 5, 1-17. [CrossRef]

36. Alavi, M.; Leidner, D.E. Research commentary: Technology-mediatedlearning-A call for greater depth and breadth of research. Inform. Syst. Res. 2001, 12, 1-10. [CrossRef]

37. Calvo, A.; Mingorance-Arnáiz, A. Valoración universitaria de la formación de competencias: El esfuerzo y la satisfacción de los estudiantes. Educ. Siglo XXI 2011, 29, 283-312.

38. Lazibat, T.; Baković, T.; Dužević, I. How perceived service quality influences students' satisfaction? Teachers' and students' perspectives. Total Qual. Manag. Bus. Excell. 2014, 25, 923-934. [CrossRef]

39. Richardson, S.; Radloff, A. Allies in learning: Critical insights into the importance of staff-student interactions in university education. Teach. High Educ. 2014, 19, 603-615. [CrossRef]

40. Díaz-Vázquez, R.; Freire, M.P.; Martínez-Roget, F.; Maside, J.M.; Río, M.L.; Vázquez-Rozas, E. La importancia de los TFG en la carga docente del profesorado y evaluación por parte del alumnado. In Proceedings of the XII Foro Internacional Sobre la Evaluación de la Calidad de la Investigación y la Educación Superior, Seville, Spain, 9-11 July 2015.

41. Todd, M.J.; Smith, K.; Bannister, P. Supervising a social science undergraduate dissertation: Staff experiences and perceptions. Teach. High Educ. 2006, 11, 161-173. [CrossRef]

42. De Kleijn, R.; Mainhard, T.; Meijer, P.; Pilot, A.; Brekelmans, M. Master's thesis supervision: Relations between perceptions of the supervisor-student relationship, final grade, perceived supervisor contribution to learning and student satisfaction. Stud. High. Educ. 2012, 37, 925-939. [CrossRef]

43. Vergara, J.C.; Quesada, V.M. Análisis de la calidad en el servicio y satisfacción de los estudiantes de Ciencias Económicas de la Universidad de Cartagena mediante un modelo de ecuaciones estructurales. REDIE 2011, 13, 108-122.

44. Richardson, J.T.E. Instruments for obtaining student feedback: A review of the literature. Assess. Eval. High. Ed. 2005. 30, 387-415. [CrossRef]

45. Oliver, R.L. Cognitive, affective, and attribute bases of the satisfaction response. J. Consum. Res. 1993, 10, 418-430. [CrossRef]

46. Spreng, R.A.; Mankenzie, S.B.; Olshavsky, R.W. A reexamination of the determinants of consumer satisfaction. J. Mark. 1996, 60, 15-32. [CrossRef]

47. Cacioppo, J.T.; Petty, R.E.; Kao, C.F. The Efficient Assessment of Need for Cognition. J. Pers. Assess. 1984, 48, 306-307. [CrossRef] [PubMed]

48. Del Barrio, S. La publicidad comparativa como estrategia publicitaria: Influencia de determinados elementos moderadores en su eficacia. Ph.D. Thesis, University of Granada, Granada, Spain, 2000.

49. George, D.; Mallery, M. SPSS for Windows Step by Step: A Simple Guide and Reference, 17.0 Update, 10th ed.; Pearson: Boston, MA, USA, 2010.

50. Hair, J.F.; Black, W.C.; Babin, B.J.; Anderson, R.E. Multivariate Data Analysis: A Global Perspective, 7th ed.; Pearson Education International: Upper Saddle River, NJ, USA, 2010.

51. Gravetter, F.; Wallnau, L. Essentials of Statistics for the Behavioral Sciences, 8th ed.; Wadsworth: Belmont, CA, USA, 2014. 
52. Joreskog, K.G.; Sorbom, D. LISREL 8: Scientific Software International; Scientific Software International: Chicago, IL, USA, 1995.

53. Chi, C.G.Q.; Qu, H. Examining the structural relationships of destination image, tourist satisfaction and destination loyalty: An integrated approach. Tour. Manag. 2008, 29, 624-636. [CrossRef]

54. Bentler, P.M. Comparative fit indexes in structural models. Psychol. Bull. 1990, 107, 238-246. [CrossRef]

55. Schermelleh-Engel, K.; Moosbrugger, H.; Müller, H. Evaluating the Fit of Structural Equation Models: Tests of Significance and Descriptive Goodness of Fit Measures. MPR-Online 2003, 8, 23-74.

56. Chen, C.F.; Tsai, D. How destination image and evaluative factors affect behavioral intentions? Tour. Manag. 2007, 28, 1115-1122. [CrossRef]

57. Browne, M.W.; Cudek, R. Alternative ways of assessing model fit. In Testing Structural Equation Models; Bollen, K.A., Long, J.S., Eds.; Sage Publications: Newbury Park, CA, USA, 1993; pp. 136-162.

58. Martínez, P.; González, N.; González, C. Percepción de competencias y plan de mejora para la consolidación de los títulos de grado en educación: La mirada de los estudiantes. Estud. Pedagóg. 2016, 3, 277-292. [CrossRef]

59. Freire, M.J.; Teijeiro, M.M.; Pais, C. La adecuación entre las competencias adquiridas por los graduados y las requeridas por los empresarios. Rev. Educ. 2013, 362, 13-41.

60. Rautopuro, J.; Vaisanen, P. Keep the customer satisfied. A longitudinal study of students' emotions, experiences and achievements at the University of Joensuu. In Proceedings of the European Conference on Educational Research, Edinburgh, Scotland, 20-23 September 2000.

61. Pérez, J.A.; Lozano, J.A.; Gómez, M.; Aguilera, A. Diseño de un instrumento para la evaluación de la del Grado en Psicología de la Universidad de Sevilla. Rev. Enseñ. Univ. 2010, 36, 45-61.

62. Río, M.L.; Díaz-Vázquez, R.; Maside, J.M. Satisfaction with the supervision of undergraduate dissertations. Act. Learn. High. Educ. 2017, 19, 159-172. [CrossRef]

63. Martínez, E.; Raposo, M. Funciones generales de la tutoría en el Practicum: Entre la realidad y el deseo en el desempeño de la acción tutorial. Rev. Educ. 2011, 354, 155-181.

(C) 2020 by the authors. Licensee MDPI, Basel, Switzerland. This article is an open access article distributed under the terms and conditions of the Creative Commons Attribution (CC BY) license (http://creativecommons.org/licenses/by/4.0/). 